УДК 343.14

DOI https://doi.org/10.32837/pyuv.v0i5(34).663

\author{
О.П. Метелев \\ orcid.org/0000-0003-2969-8388 \\ старший викладач спеиіальної кафедри № 2 \\ Інституту підготовки юридичних кадрів для Служби безпеки України \\ Національного юридичного університету імені Ярослава Мудрого
}

\title{
ПІДСТАВИ ДЛЯ ПРИЙНЯТТЯ РІШЕННЯ ЩОДО ЗНЯТТЯ ІНФОРМАЦІЇ 3 ТРАНСПОРТНИХ ТЕЛЕКОМУНІКАЦІЙНИХ МЕРЕЖ У КРИМІНАЛЬНОМУ ПРОВАДЖЕННІ
}

Постановка проблеми. Пізнання у кримінальному провадженні здійснюється виключно за допомогою кримінального процесуального доказування - врегульованої законом процесуальної діяльності, що згідно з положеннями ч. 2 ст. 91 Кримінального процесуального кодексу України (далі - КПК) полягає у збиранні, перевірці та оцінці доказів з метою встановлення обставин, що мають значення для кримінального провадження [1]. Зняття інформації з транспортних телекомунікаційних мереж (далі - ТTM) є одним iз найбільш інформативних способів збирання доказів та відіграє одну із ключових ролей у цьому процесі. Водночас проведення будь-якої процесуальної дії в кримінальному процесі, в тому числі зняття інформації з ТTM, передбачає наявність законних підстав, тому, на наш погляд, під час прийняття відповідного процесуального рішення вкрай важливим є усвідомлення слідчим наявності таких підстав.

Огляд основних досліджень i публікацій. Питання визначення підстав прийняття кримінально-процесуальних рішень та їхні специфічні ознаки неодноразово досліджувались такими видатними вченими, як М.I. Бажанов, Ю.М. Грошевий, Н.В. Глинська, В.С. Зеленецький, П.А. Лупинська, О.I. Марочкін, О.Г. Шило, М.Є. Шумило тощо. У свою чергу інститут НСРД та різні аспекти організації та використання результатів проведення зняття інформації з ТТМ були предметом дослідження багатьох процесуалістів, зокрема: М.В. Багрія, Б.І. Бараненка, О.А. Білічака, С.О. Гриненка, В.А. Колесніка, С.С. Кудінова, В.В. Луцика, М.А. Погорецького, Д.Б. Сергєєвої, О.В. Соколова, Є.Д. Скуліша, С.Р. Тагієва, В.Г. Уварова, О.О. Юхна та інших. Незважаючи на велику кількість наукових публікацій, залишаються дискусійними та недостатньо дослідженими деякі проблемні питання щодо підстав прийняття рішення слідчим для проведення зняття інформації з ТТМ як дієвого способу збирання доказів у кримінальному процесі. Причиною того, що науковцям не вдалося дослідити та вирішити всі проблемні питання в цій сфері є те, що зняття інформації з ТТМ - це організаційно, процесуально та технічно складна негласна слідча (розшукова) дія (далі - НСРД). Крім того, відомості про факт, методи та засоби проведення цієї НСРД не підлягають розголошенню. Недостатній рівень наукової розробки цих проблемних питань негативно позначається на якісних характеристиках проведення зняття інформації з ТТМ, а також на правозастосовній практиці впровадження результатів цієї НСРД у кримінальне судочинство.

Мета статті - спираючись на аналіз наукових публікацій та норм кримінально-процесуального законодавства, дослідити підстави прийняття слідчим рішення щодо проведення зняття інформації з транспортних телекомунікаційних мереж у рамках кримінального провадження.

Виклад основного матеріалу. Цілком закономірно, що в будь-яких обставинах у людини завжди виникає необхідність здійснювати певні раціональні та цілеспрямовані дії. Такі дії здійснюються на підставі прийнятих рішень. Рішення, з наукової точки зору, як «продуманий намір зробити що-небудь, якось вчинити» відображає позицію людини щодо означеного питання [2, с. 581]. 3 логічної точки зору рішення - це судження, за допомогою яких ми створюємо гіпотези, попередні висновки щодо сутності явищ, що вивчаються. Водночас у кримінально-процесуальній діяльності $€$ певні особливості, які зумовлюють специфіку прийняття рішень. Так, М.I. Бажанов, Ю.М. Грошевий, В.С. Зеленецький, П.А. Лупинська у своїх роботах справедливо пропонують розглядати кримінально-процесуальні рішення як процесуальні акти, в яких завжди даються відповіді на правові питання, що виникають у ході провадження $[3 ; 4 ; 5 ; 6]$. У свою чергу термін «акт» тлумачиться у двох змістовних значеннях: як дія (окремий прояв якої-небудь діяльності; дія, подія, вчинок) і як документ (офіційний документ, протокол, запис про який-небудь факт). Можливо погодитися 3 В.С. Зеленецьким та Н.В. Глинською щодо сформульованого ними визначення кримінально-процесуального рішення, під яким науковці розуміють «виражений у встановленій законом формі індивідуальний правозастосовний акт, в якому компетентні державні органи і посадові особи у відповідному порядку з метою вирішення правових і кримінологічних 
завдань кримінального процесу дають відповіді на виникаючі за справою питання і висловлюють власне волевиявлення щодо дій або бездіяльності, які випливають із визначених на момент винесення рішення фактичних обставин справи і приписів діючого законодавства» [7, с. 20].

Аксіоматичним є положення про те, що в кримінально-процесуальній науці будь-яке рішення, що приймається в ході кримінального судочинства, має бути не тільки законним, але й обгрунтованим. Це у свою чергу забезпечує належне збирання доказово значущих відомостей з дотриманням прав і свобод особи, а також суттєво впливає на швидкість розкриття злочинів. До того ж така вимога обгрунтованості процесуальних рішень відповідає міжнародним стандартам щодо захисту прав людини.

Необхідно зазначити, що в процесуальній науці немає єдності щодо визначення підстав для провадження тих чи інших слідчих (розшукових) дій, у тому числі й зняття інформації з ТТМ. Так, А.Я. Дубинський наголошує, що всі процесуальні рішення «повинні спиратись на достовірні докази, які не піддають сумніву правильність зробленого висновку <...>, як підстави повинна розглядатися сукупність доказів, достатніх для того, щоб прийняти конкретне рішення» [8, с. 21-22]. Позицію, відповідно до якої підставами для прийняття процесуальних рішень у кримінальному провадженні можуть бути лише докази, підтримували багато вчених: П.А. Лупинська, Н.П. Кузнецов та інші. Проте така позиція не відповідає вимогам сучасного кримінального процесу. Так, Д.Б. Сергєєва вважає, що «на початковому етапі розслідування в уповноваженої особи ще може не бути доказів, визначених ст. 84 КПК України, які би були підставами для прийняття нею таких рішень, оскільки процесуальні докази отримуються лише у визначеній законом формі шляхом провадження передбачених ст. 93 КПК України заходів» $[9$, с. 59$]$.

Інші вчені, зокрема М.А. Погорецький, допускають врахування при цьому й оперативно-розшукової інформації [10, с. 398-399]. Розуміючи роль відомостей, отриманих у результаті проведення оперативно-розшукових заходів як підстав для прийняття слідчим процесуальних рішень у кримінальному провадженні, М.Є. Шумило запропонував внести зміни в КПК та сформулювати окрему норму «Підстави для проведення слідчих дій» такого змісту: «Підставами для проведення слідчих дій можуть бути докази, матеріали кримінальної справи та оперативно-розшукові дані, що вказують на необхідність і можливість проведення відповідної слідчої дії з метою одержання доказів» [11, с. 995].

Отже, можемо сформулювати, що для прийняття процесуального рішення про проведення зняття інформації з ТТМ слідчий має спиратися на відповідні відомості (у тому числі оперативно-розшукові дані або такі, що отримані в результаті проведення інших слідчих (розшукових) дій), які б з певним ступенем імовірності вказували на можливість отримання доказів.

Необхідно зазначити, що багато вчених намагались сформулювати структуру підстав для прийняття рішення про проведення слідчих (розшукових) дій. Так, Ю.П. Аленін, розглядаючи підстави для прийняття рішення щодо проведення слідчих дій, стверджує, що для їх провадження «необхідна наявність юридичних та фактичних підстав». На думку науковця, «юридичні підстави - це вказівки, що містяться в законі, на правомочність слідчого проводити певні слідчі дії i наявність відповідної постанови, а у випадках, передбачених законом, - санкції прокурора або дозволу суду», фактичні підстави - це «фактичні дані, що є в розпорядженні слідчого, i які дозволяють зробити висновок про необхідність провадження в інтересах слідства певної слідчої дії. Ці дані не обов'язково мають носити характер доказів по справі, вони можуть бути отримані з непроцесуальних джерел» [12, с. 30]. Д.Б. Сергєєва, досліджуючи підстави провадження НСРД, також вважає за доцільне розмежовувати фактичні й правові (юридичні) підстави провадження слідчих дій, проте зазначає, що «юридичні (правові) підстави проведення процесуальних дій, у тому числі й НСРД, мають два аспекти - широкий та вузький. У широкому аспекті під юридичною (правовою) підставою слід розуміти наявність відповідних законодавчих норм, що регламентують можливість проведення тієї чи іншої процесуальної дії. У вузькому розумінні юридичною (правовою) підставою є відповідний процесуальний документ, складений згідно із встановленими законом вимогами, що надає право відповідному суб’єкту здійснювати ту чи іншу процесуальну дію» $[9$, с. 56].

У свою чергу, O.I. Марочкін, розробляючи своє тлумачення фактичних і правових підстав, доповнює цей перелік етичними підставами. Науковець стверджує, що «не завжди для належного мотивування рішення слідчому достатньо спиратись на фактичні та правові підстави. Так, у деяких випадках (насамперед ідеться про рішення слідчого, які стосуються конституційних прав і свобод осіб) він має справу з моральними, етичними категоріями. Тож етичні підстави для прийняття слідчим рішень - це сукупність правил поведінки, норм моралі, які панують у суспільстві та дають змогу оцінити діяльність слідчого та обставини, які мають значення для кримінального провадження, з погляду моралі» [13, с. 51-52]. Однак, на думку автора, вбачається, що етичні й моральні категорії вже враховані у вітчизняному законодавстві, як час розроблення 
Конституції та інших правових норм, так і шляхом імплементації норм міжнародного права, які втілюють і захищають морально-правові цінності (гуманізм, гласність, рівність прав сторін, справедливість тощо), а також є загальною правовою основою для більшості національних законодавств.

Таким чином, підсумовуючи різні наукові теоретичні погляди та практичні напрацювання процесуалістів, можливо зробити висновок, що структура підстав (сукупності умов) для прийняття рішення про проведення зняття інформації з ТTМ має такі елементи:

1. Фактична основа - це сукупність відомостей (під якими розуміються результати ОРД, матеріали кримінального провадження, інші доказові відомості), які зумовлюють необхідність і можливість проведення зняття з ТTМ у конкретних умовах (тобто те, що маємо в дійсності);

2. Інформаційна основа - визначає, які саме є відомості про фактичні підстави прийняття рішення про проведення зняття інформації з ТTМ (чи їх достатньо або недостатньо, вони надійні або ненадійні, вони знаходяться в матеріалах оперативно-розшукової справи або кримінального провадження тощо);

3. Нормативно-правова основа - це наявність прямих вказівок кримінально-процесуального закону щодо проведення зняття інформації з ТTМ в єдності з процесуальною формою рішення про проведення цієї НСРД, а також наявність відповідних повноважень посадових осіб і органів.

На наш погляд, саме така структура підстав для прийняття рішення про проведення зняття інформації з ТТМ дозволить слідчому прийняти правильне грунтовне процесуальне рішення, яке, як уже зазначалось, має ймовірний характер і найчастіше приймається в умовах ризику та інформаційної невизначеності. Зазначимо, що неможливо розглядати ці підстави окремо одну від одної, як це часто відбувається в кримінально-процесуальній науці. Необхідно ще раз підкреслити, що підстава для проведення зняття інформації з TTM одна, але вона має комплексний характер це сукупність умов (фактичних, інформаційних та нормативно-правових), які визначають можливість проведення цієї НСРД.

Враховуючи вищевказані наукові позиції процесуалістів, вважаємо, що підстави для проведення зняття інформації з ТТМ доцільно розглядати як конструкцію, яка складається з інформаційних і правових чинників. Інформаційні підстави для проведення даної НСРД є підгрунтям, на основі якого слідчим у кримінальному провадженні приймаються відповідні управлінські рішення, результатом яких $\epsilon$ кінцевий продукт - сукупність необхідних умов (певні формалізовані юридичні документи), які i визначають правові підстави для проведення зняття інформації з ТTМ.
Якщо звернутись до норм КПК, то можна побачити, що загальними підставами (інформаційними) проведення слідчих (розшукових) дій законодавець убачає наявність достатніх відомостей, що вказують на можливість досягнення іï мети (п. 2 ст. 223 КПК). У свою чергу згідно 3 п. 2 ст. 246 КПК у випадках, якщо відомості про злочин та особу, яка його вчинила, неможливо отримати в інший спосіб, то на підставі ухвали слідчого судді (юридичного документу, який є правовою підставою проведення заходу) виключно у кримінальному провадженні щодо тяжких або особливо тяжких злочинів проводиться така НСРД, як зняття інформації з ТТМ. Така ж сама правова підстава вказана і в ст. 263 КПК: «зняття інформації з транспортних телекомунікаційних мереж ... є різновидом втручання у приватне спілкування, яке проводиться без відома осіб, які використовують засоби телекомунікацій для передавання інформації, на підставі ухвали слідчого судді, якщо під час його проведення можна встановити обставини, які мають значення для кримінального провадження <...> в ухвалі слідчого судді про дозвіл на втручання у приватне спілкування, в цьому випадку додатково повинні бути зазначені ідентифікаційні ознаки, які дозволять унікально ідентифікувати абонента спостереження, транспортну телекомунікаційну мережу, кінцеве обладнання, на якому може здійснюватися втручання у приватне спілкування» [1].

Необхідно зазначити, що вибір слідчим такого процесуального рішення, як проведення НСРД у вигляді зняття інформації з ТTМ, зумовлено впливом зовнішніх і внутрішніх факторів, до яких практичні працівники відносять: дефіцит часу; відсутність (недостатність) відомостей про обставини, що підлягають доказуванню в кримінальному провадженні; надійність джерел отриманих відомостей в умовах, коли слідчий не має можливості перевірити їх 3 інших позицій; можливий психологічний тиск із боку як керівництва, так і підозрюваних (обвинувачених); вплив інших учасників процесу на слідчого; недостатність (некомпетентність, відсутність) кадрового та недосконалість (застарілість, відсутність) технічного ресурсів для проведення даного виду НСРД тощо. Зазначені фактори визначають специфіку, своєчасність та обгрунтованість прийняття рішень слідчим щодо проведення зняття інформації з ТTM та впливають на їхню ефективність і своєчасність. Відповідно, слідчий повинен бути емоційно, психологічно та професійно підготовленим для того щоб бути спроможним подолати ці перешкоди організувати ефективне проведення даного виду НСРД, оскільки приймати рішення і діяти йому доводиться в умовах ризику та інформаційної невизначеності. 
Висновки i перспективи подальших досліджень. Підсумовуючи вищевикладене, зазначимо, що процесуальне рішення слідчого щодо організації та проведення зняття інформації з ТТМ має складну інформаційну природу. Воно знаходиться в безпосередній залежності від кількості та якості інформації, якою володіє слідчий під час прийняття цього процесуального рішення. Від цього залежить винесення однозначного висновку щодо доцільності прийняття рішення про проведення зняття інформації з ТТМ та її ефективне проведення.

Крім того, вбачається за необхідне забезпечити чіткість та ясність законодавчого визначення інформаційних і правових підстав для проведення зняття інформації з ТТМ в окремій нормі КПК. Це, безперечно, сприятиме їх однозначному усвідомленню і розумінню, що у свою чергу підвищить практичну ефективність застосування норм закону слідчими, прокурорами та судами задля забезпечення гарантій прав і свобод людини під час здійснення кримінального провадження.

\section{Jimepamypa}

1. Кримінальний процесуальний кодекс України : Закон України від 13 квітня 2012 р. № 4651-VI (у ред. від 11 вересня 2020 р.). URL: http://zakon5.rada.gov.ua/laws/show/4651-17 (дата звернення: 10.12.2020).

2. Словник української мови : в 11 томах / ред. тому : В.О. Винник та ін. ; АН УРСР. Київ : Наукова думка, 1977. Т. 8. 927 с.

3. Аленин Ю.П. Процессуальные особенности производства следственных действий. $K$-д: ЦентральноУкраїнське вид-во, 2002. 264 с.

4. Бажанов М.И. Законность и обоснованность основных судебных актов в советском уголовном судопроизводстве : дисс. ... д-ра юрид. наук : 12.00.00. Харьков, 1966. 523 с.

5. Грошевой Ю.М. Сущность судебных решений в советском уголовном процессе. Харьков : Вища школа, 1986. 183 с.

6. Дубинский А.Я. Исполнение процессуальных решений следователя. Правовые и организационные проблемы. Киев : Наукова думка, 1984. 182 с.

7. Зеленецкий В.С. Возбуждение государственного обвинения в советском уголовном процессе. Харьков : Вища школа, 1979. 145 с.

8. Зеленецкий В.С., Глинская Н.В. Теория и практика обоснования решений в уголовном процессе Украины. Харьков : Страйд, 2006. 336 с.

9. Лупинская П.А. Решения в уголовном судопроизводстве: Их виды, содержание и формы. Москва : Юрлит., 1976.168 с.

10. Марочкін O.I. Мотивування процесуальних рішень слідчого : монографія. Київ : Національна академія прокуратури України, 2015. 214 с.

11. Погорецький М.А. Функціональне призначення оперативно-розшукової діяльності у кримінальному процесі : монографія. Харків : Видавництво «Арсіс ЛТД», 2007. 576 с.

12. Сергєєва Д.Б. Правові та фактичні підстави провадження негласних слідчих (розшукових) дій. Вісник крилінального судочинства. Київ, 2017. № 4. C. 56-65.

13. Шумило М.Є. Вибрані праці. Харків : Право, 2019,1168 c.

\section{Анотація}

Метелев О. П. Підстави для прийняття рішення щодо зняття інформації з транспортних телекомунікаційних мереж у кримінальному провадженні. - Стаття.

У даній статті на основі аналізу наукових публікацій та норм кримінально-процесуального законодавства досліджуються підстави прийняття слідчим рішення щодо проведення зняття інформації транспортних телекомунікаційних мереж у межах кримінального провадження. Аналізуються наукові публікації стосовно підстав для провадження негласних слідчих (розшукових) дій (зокрема, зняття інформації 3 транспортних телекомунікаційних мереж). Робиться висновок, що для прийняття процесуального рішення про проведення зняття інформації з транспортних телекомунікаційних мереж слідчий повинен мати відповідні відомості (у тому числі оперативно-розшукові дані або такі, що отримані в результаті проведення інших слідчих (розшукових) дій у межах кримінального провадження), які б з певним ступенем імовірності вказували на можливість отримання доказів, значущих для кримінального провадження. Крім того, автором зазначається, що проведення зняття інформаціі транспортних телекомунікаційних мереж здійснюється в умовах професійного ризику. Цей факт має важливе значення для належного формулювання підстав для проведення такої негласної слідчої (розшукової) дії, оскільки: по-перше, вона проводиться в умовах таємності, $з$ дотриманням вимог конспірації і легендування, а по-друге, цифрова інформація має швидкоплинний характер, і тому рішення про проведення такого заходу приймається в умовах невизначеності. У статті автором сформульована структура підстав (сукупності умов) для прийняття рішення для проведення такої негласної слідчої (розшукової) дії, як зняття інформації з транспортних телекомунікаційних мереж. У статті робиться висновок, що зняття інформації транспортних телекомунікаційних мереж передбачає наявність чітко визначених підстав для прийняття слідчим вмотивованого кримінально-процесуального рішення щодо проведення цієї негласної слідчої (розшукової) діï. У зв'язку з цим вкрай важливою є необхідність розуміння та однозначного усвідомлення слідчим законних підстав (умов) прийняття ним такого кримінально-процесуального рішення.

Ключові слова: кримінальне провадження, підстави, транспортні телекомунікаційні мережі, цифрова інформація.

\section{Summary}

Metelev O. P. Grounds for making a decision on withdrawal of information from transport telecommunication networks in criminal proceedings. Article.

In this article, based on the analysis of scientific publications and norms of criminal procedure legislation, the grounds for the investigator's decision to withdraw information from transport telecommunications networks in criminal proceedings are investigated. Scientific publications on the grounds for conducting covert investigative (search) actions (in particular, the removal of information from transport telecommunications networks) are analyzed. It is concluded that in order to make a procedural decision to withdraw information from transport 
telecommunications networks, the investigator must have relevant information (including operational and investigative data or those obtained as a result of other investigative (investigative) actions in criminal proceedings). This information, to a certain degree of probability, would indicate the possibility of obtaining evidence relevant to the criminal proceedings.

In addition, the author notes that the decision-making and withdrawal of information from transport telecommunications networks is carried out in conditions of professional risk. This fact is important for the proper formulation of the grounds for such covert investigative (search) action by several reasons. First, it is carried out by a limited number of authorized entities that take the necessary measures not to disclose the fact of such actions and digital information received. Secondly, this digital information is transient and therefore the decision to withdraw information from transport telecommunications networks is made in conditions of uncertainty.

In the article the author formulates the structure of the grounds (set of conditions) for making the decision for carrying out such covert investigative (search) action. The article concludes that the withdrawal of information from transport telecommunications networks implies the existence of clearly defined grounds for the investigator to make a reasoned criminal procedure decision to conduct this covert investigative (search) action. In this regard, it is extremely important that investigators are aware and unambiguously understand the legal grounds (conditions) for making such a criminal procedure decision.

Key words: criminal proceedings, grounds, transport telecommunication networks, digital evidence. 